\title{
A COVID-19 JÁRVÁNY HATÁSAI AZ ELEKTROMOS AUTÓK LÍTIUM-ION AKKUMULÁTORAIT GYÁRTÓ KOMÁROMI SK BATTERY HUNGARY KFT. ESETÉBEN
}

\author{
DR. PEREDY ZOLTÁN, intézetvezető \\ EDUTUS Egyetem \\ peredy.zoltan@edutus.hu
}

VENCZEL MÁRK, doktorandusz

BME Vasúti Jármüvek, Repülőgép és Hajók Tanszék

mvenczel@vhrt.bme.hu

DOI 10.47273/AP.2020.20.85-105

\begin{abstract}
ABSZTRAKT
A COVID-19 járvány a hagyományos belsőégésủ motorral (ICE) felszerelt autókat gyártó jármüipari szegmenst jelentősen visszavetette, felerősítve a kontinenseken átívelő, koncentrált, hosszúra nyúlt termelési láncok problémáit. Ugyanakkor - amint látni fogjuk a tanulmányban - az elektromos hajtásláncú jármüveket (EV) és ezek erőforrásait, a lítium-ionos akkumulátorokat (LIB) gyártó szegmensre nem gyakorolt szignifikáns hatást a koronavírus járvány. Ezen okok elemzése és megértése alapvető lehet Magyarország és ezen belül Komárom-Esztergom megye (KEM) számára, amelynek gazdaságában egyik húzóágazatként jelentős súllyal szerepel a jármüipar, ahol a régió egyetlen felsőoktatási intézménye, a tatabányai székhelyü Edutus Egyetem is müködik, kulcsszereplőként a megye számára szükséges magasan képzett munkaerő biztosításában, és a helyi kis-és középvállalati (KKV) szektor versenyképességének növelésében.

Az esettanulmányban bemutatott, LIB gyártó komáromi SK Battery Hungary (SK BH) üzleti folyamataira a járvány nem gyakorolt hatást, a felfutóban lévő gyártó kapacitások kiépítése zavartalanul folytatódott. Ennek okai az EV iránti kereslet jövőbeli felfutása mellett a dél-koreai céges kultúrában keresendő, amely mindig is törekedett a külföldtől való függetlenedésre. Ez megnyilvánul a saját beszállítói láncának rövidítésében és optimalizálásában (a szintén Komárom-Esztergom megyébe betelepült dél-koreai beszállítókkal és alvállalkozókkal dolgoztatás), amely sikeresnek bizonyulhat a későbbiekben is, csökkentve a járvány hatásainak való kitettséget.

A koronavírustól függetlenül az utóbbi időben elindult egy alkalmazkodási folyamat a magyar cégek körében is, amelyek szintén igyekeznek újra pozícionálni a termelésüket, újra gondolva a munkaerő-kapacitást, a termelési láncstruktúrát, és a készletezési politikát. Ebben segíthet a fenti példa végig gondolása is.
\end{abstract}

Kulcsszavak: COVID-19, EV, LIB, SK Battery Hungary, rövidített és optimalizált beszállítói láncok 


\begin{abstract}
The COVID-19 epidemic had negative impact on the automotive segment that manufactures cars with conventional internal combustion engines (ICE), exacerbating the problems of concentrated, lengthy production chains across continents. However, the segment producing electric powertrain vehicles (EV) and their resources, lithium-ion batteries (LIB), was not significantly affected by the coronavirus pandemic as you can see in this study. The analysis and understanding of these reasons beyond this trend can be essential for Hungary including Komárom-Esztergom county (KEM) as well, where the automotive industry is one of the strategic sector in the regional economy. The private HEI, the Edutus University located also here in its HQ in Tatabánya that should play pivotal role increasing the competitiveness of the local SME sector and provide the well-educated and skilled labour workforce for the local companies.

In this case study, the example of South Korean global chaebol, the SK Innovation owned SK Battery Hungary (SK BH) is presented, which located in Komárom Industrial Park and its business operation processes had not been influenced by the COVID-19, since the production and the enlargement of the capacities managed to continue uninterrupted. The reasons can be found in the South Korean corporate culture, which has always strived to be independent from abroad. This reflecting in shortening and optimization of its own supply chain (working with South Korean suppliers and subcontractors also settled in Komárom-Esztergom county), which may prove successful strategy in the future, reducing exposure to the effects of the epidemic. Independently from the coronavirus pandemic, an adjustment process has recently started among Hungarian companies, aiming to reposition their production, rethinking their workforce capacity, supply chain structure and inventory policy. Taking into consideration the above example can contribute to a successful implementation of these efforts into practice.
\end{abstract}

Keywords: COVID-19, EV, LIB, SK Battery Hungary, shortened and optimised supply chains

\title{
1. Bevezetés
}

Az elmúlt években a jármüiparban megfigyelhető globális trend az elektromos jármügyártás elötérbe kerülése, az eladott különböző típusú elektromos járművek számának növekedése, amelynek okai összetettek: a fenntarthatóság és klímavédelem szempontjából egyre szigorodó környezetvédelmi normák, a dízelbotrány, a technológiai fejlődés, amely elérhető közelségbe hozta a megfizethető árszintü, nagyobb hatótávolságú és hosszabb üzem idejü akkumulátorokkal rendelkező, a városi mobilitás optimalizálását lehetővé tevő modelleket. (IEA 2020)

A COVID-19 járvány a hagyományos belsőégésű motorral felszerelt autókat gyártó jármüipari szegmenst jelentősen visszavetette, felerősítve a kontinenseken átívelő, koncentrált, hosszúra nyúlt termelési láncok problémáit. Az erős piaci verseny által kikényszerített költséghatékony, méretgazdaságos és minőség-orientált működésre való törekvés miatt számos terméknek van csak kevés számú, vagy egyetlen termelője, sokszor egy távoli országban. A just-in-time rendszerek széles körben való bevezetése és a szigorú készletgazdálkodás is hozzájárul ezen 
struktúra külső tényezőknek való kitettségéhez. Ugyanakkor az elektromos autókat és akkumulátorokat gyártó szegmensre nem gyakorolt szignifikáns hatást a koronavírus járvány. Ezen okok elemzése és megértése alapvető lehet Magyarország és ezen belül KomáromEsztergom megye számra (amelynek gazdaságában egyik húzóágazatként jelentős súllyal szerepel a jármüipar, ahol a régió egyetlen felsőoktatási intézménye a tatabányai székhelyü Edutus Egyetem is müködik kulcsszereplőként a megye számára szükséges magasan képzett munkaerő biztosításában és helyben tartásában).

Jelen cikk a dél-koreai SK Innovation 100\%-os tulajdonában lévő, komáromi telephellyel müködő, az elektromos járművek számára szükséges lítium-ion akkumulátorokat (LIB) gyártó SK Battery Hungary beruházási döntéseinek hátterét és a gyártókapacitásainak felfutását és müködési folyamatainak ,járvány állósági” okait elemezi a hasznosítható tanulságok levonásával. A bemutatott esettanulmány hozzájárulhat a Komárom-Esztergom megyei cégek COVID-19 járvány valószínűsíthető újabb hullámaival szembeni kitettségük mértékének csökkentéséhez, növelve a hazai vállalkozások számára korábban meghozott gazdaságvédelmi intézkedések hatékonyságát (OECD 2020).

\section{Kutatási módszertan}

A nemzetközi áttekintés a szekunder vagy „desk research” kutatási módszerekre támaszkodik (meglévő releváns dokumentumok /IEA, EEA, OECD, EC, Bloomberg, Benchmark Mineral Intelligence/, publikációk, statisztikai adatbázisok, online weboldalak átnézése, majd az így összegyüjtött adatok rendszerezése, szelektálása, elemzése). Emellett primer információk felhasználásával (SK Battery Hungary vezetőivel mini fókuszcsoportos interjú, Komáromi Ipari Park koordinátorával történő mélyinterjú alapján) készült a példaként bemutatott esettanulmány. A nemzetközi tapasztalatokra épülő, a konkrét példára vonatkozó elemzésből levont főbb következtetések a szerzők saját szakmai véleményét tükrözik.

\section{Struktúraváltás a jármúiparban}

\subsection{Az elektromos jármügyártás elötérbe kerülése}

Az elektromos meghajtású jármüvek kategóriái (Budde-Meiwes, Heide et at. 2013; EEA 2018):

- Hidrid elektromos jármü (HEV): a meghajtás két részből áll, egy elektromos motorból és egy belsőégésű egységből. Egy HEV minden esetben képes teljesen elektromos, hibrid és klasszikus belsőégésű hajtással közlekedni. A kategórián belül 
szokás még a mikro-HEV, enyhe (mild) HEV és a teljes (strong) HEV csoportokat is megkülönböztetni a kétféle hajtáslánc egymáshoz viszonyított arányától függően.

- Plug-in-hibrid (PHEV): A plug-in hibrid szinte megegyező egy hibrid hajtáslánccal. A különbség azonban, hogy a plug-in hibridet már nem csak az elektromos generátor vagy belső égésű motor (ICE) segítségével lehet feltölteni. Léteznek kifejezetten erre kialakított töltőállomások, de akár a saját otthonában is töltheti egy fali töltőről a tulajdonos. Amikor pedig az elektromos akkumulátorok lemerülnek, átvált a rendszer a hagyományos hibrid hajtásmódra.

- Akkumulátormeghajtású elektronos jármü (BEV): a teljesen elektromos jármü, amelynek energiáját egy elektromos hajtáslánc és akkumulátorpakk, vagy pakkok biztosítják. Nincsen ICE vagy üzemanyag tartály, és a töltést, mint azt a PHEV esetében külső egységről kell megoldani.

A jármüiparban elinduló belső átrendeződésének valószínű okai között a környezet- és klímavédelmi előírások szigorodása mellett például a dízelbotrány is szerepet játszhatott (Jae C. Chung et at. 2019; Christian Brand 2016), amely a hagyományos belső égésű motoros járművek iránti kereslet visszaesésével egyidőben, az elektromos meghajtású jármüvek /BEV, PHEV, HEV/) előtérbe kerülését eredményezte.

Az Egyesült Államok Környezetvédelmi Ügynöksége (EPA) 2015 szeptemberében megvádolta a gyártót, hogy olyan szoftvert telepített 482 ezer dízelüzemü jármű kipufogógáz-tisztító berendezésébe, amely érzékeli a mérés körülményeit. Az autó így a teszteken a valóságos nitrogén-oxid-kibocsátás töredékét produkálta, vagyis csalt a vizsgán. A VW elismerte a csalást. Az ügy világszerte a VW mintegy 11 millió gépjármüvét érintette, ezek közül 8,5 milliót az EU-ban adtak el. Azóta pedig a Daimler is elismerte, hogy érintett a dízelbotrányban, valamint a Fiat Chrysler Jeep Grand Cherokee, és a Suzuki Vitara dízelmotoros modelljeiröl derült ki, hogy megsértik az uniós emissziós normákat. Az Európai Unióban referenciának tekintett holland gépjármü-felügyelet az RDW közleménye szerint az érintett Jeep és Suzuki modellek értékesítését be kell tiltani, amennyiben a gyártók nem nyújtanak megoldást a problémára. (Jae C. Chung et at. 2019; Janene Pieters 2017 és 2020)

Mivel a szélesebb tömegek számára is elérhető elektromos modellekre, valamint a töltőinfrastruktúra dinamikus fejlesztésére van szükség ahhoz, hogy az autógyártók képesek legyenek teljesíteni az elöírásokat, ezért intenzív fejlesztések indultak el az elektromos autók vonalán, amelyek hozzájárultak a vásárlói döntéseknek az elektromos járművek irányába történő elmozdításához (elsősorban a városi mobilitás optimalizálásában). Új korszak kezdődött az autógyártásban, ahol az új belépők a régi szereplők pozícióira törnek, olyan 
versenybe kényszerítve őket, amely felgyorsítja a belsőégésű motorok „kifutását”. (Yeon Baik et at. 2019).

Globális szinten 2010-ben 17 ezer elektromos autó közlekedett, 2019-re ez a szám 7,2 millióra növekedett, amelyből 47 \%-t a Kínai Népköztársaság képvisel, de másik 20 országban is elérte vagy meghaladta az eladott elektromos autók részaránya az 1\%-t az összesen eladott autók arányához viszonyítva. (IEA 2020)

Az elektromos autók elterjedésével előtérbe kerülnek az autómegosztó szolgáltatások is. Sok ember számára nincs értelme beruházni egy saját, akár elektromos modellre, ezt pedig a gyártók is kezdik felmérni. A vállalatok az autómegosztó szolgáltatások felé veszik az irányt flottaüzemeltetővé válva pedig felvehetik a versenyt az olyan szolgáltatókkal, mint az Uber vagy a Didi. Az autómegosztó szolgáltatások egyébként már nagy népszerüségnek örvendenek a fiatalabb generációk körében, főleg a nagyobb városokban, ahol rövidesen korlátozni fogják az autók számát, és a közösségi közlekedés sokkal nagyobb hangsúlyt kap majd.

\subsection{A COVID-19 járvány hatásai a jármüipari elektromos autók szegmensére}

A különböző országok kormányai elkötelezettek a fenntarthatósági, klímavédelmi, környezetvédelmi szempontok (károsanyagok kibocsátása, a légszennyezés csökkentése, hulladékok újra hasznosítása, alternatív hajtásláncok, a gazdaság zöldítése) teljesítése irányában. Erre példa az Európai Zöld Megállapodás, amely az előbbi célok megvalósításához adja meg a szükséges kereteket. Ennek egyik eleme, hogy olyan államilag támogatott projekteket kell indítani, amelyek segítik az olyan új, innovatív értékláncok kiépítését, mint a biztonságos, körforgásos és fenntartható akkumulátor-gyártókapacitások kialakítása az elektromos járművek növekvő piacának ellátására. (Európai Bizottság COM /2019/ 640 final)

Az Európai Zöld megállapodás alapján az Európai Bizottság 2020. márciusában elindította „A körkörös gazdaság új cselekvési terve a tisztább és versenyképesebb Európáért" nevü tervezési folyamatot, amelyben egyik kiemelt prioritás az akkumulátorok és elektromos jármúvek.

Az Európai Környezetvédelmi Ügynökség szerint egy elektromos személyautó teljes élettartama alatt, országtól függően 17-30\%-kal kevésbé terheli a környezetet, mint a hasonló ICE megfelelője. (EEA 2018).

A fentiek miatt számos országban (néhány példa Kína, Egyesült Királyság, Németország, Japán, Dél-Korea) jelentős állami szubvenciókkal ösztönzik a döntéshozók az elektromobilitás elterjedését. Kína nemrégiben meghosszabbította támogatási rendszerét 2022-ig, illetve Kína 
és Európa megállapodtak a belső égésű motorral felszerelt gépjárművek légszennyezőanyagkibocsátására vonatkozó előírások szigorításáról az elektromos gépjárművek gyártásának előmozdítása érdekében. Az Európai Unió a jövőben szorosabban együtt kíván müködni a G20 csoport országaival, amelyek az üvegházhatású gázkibocsátás 80\%-t okozzák (Európai Bizottság COM /2019/ 640 final).

A dokumentum szerint a Bizottság tervei között szerepel, hogy 2021 júniusáig megtörténne a személygépkocsikra és kisteherautókra vonatkozó szén-dioxid kibocsátási előírásokról szóló jogszabályok felülvizsgálata, hogy 2025-től megnyíljon az út a kibocsátásmentes mobilitás felé. Emellett mérlegelni fogja az európai kibocsátáskereskedelem közúti közlekedésre való alkalmazását, a jármüvekre vonatkozó jelenlegi és jövőbeli szén-dioxid kibocsátási előírásokat kiegészítve. Az EU törekvése, hogy az általa elfogadott szabványok figyelembevételre kerüljenek a globális értékláncok esetében is. A Bizottság úgy alakítja majd a nemzetközi szabványokat, hogy azok összhangban legyenek az uniós környezet- és éghajlatvédelmi törekvésekkel.

Ezért a COVID-19 járvány jóval kisebb mértékben befolyásolta a jármüipar e szegmensét, miközben az ICE szegmens megsínylette a karantén-intézkedések miatti globális beszállítói láncok leállását. A 2020 januárjától áprilisáig tartó időszakban a szakértői becslések alapján a hagyományos gépjárművek értékesítési volumene a 2019. évihez viszonyítva $15 \%$-kal csökkent, addig az elektromos meghajtású gépjármüvek értékesítési volumene nagyjából a 2019. évi szinten maradt. Összességében az elektromos autók értékesítésének részaránya a globális autóértékesítésnek 3\%-t teszi ki 2020-ban az előrejelzések szerint. A járvány utáni gazdaság-újra indító intézkedések egy része is az elektromos jármügyártás felfuttatását fogja célozni. (Erre példa Franciaország és Németország, amelyek 2020. 2. félévére az elektromos járművek elterjedésére irányuló fokozott támogatási intézkedéseket jelentettek be. (IEA 2020; Saskia Hausler et at. 2020).

Az elektromos jármügyártó szegmens helyzete a járványt követően régiónként eltérő lehet. Kínában (és más délkelet-ázsiai országokban) az EV-k piaci részesedésének gyors és erőteljes növekedése prognosztizálható. (A Kínai Népköztársaságban a döntéshozók a járműipart a gazdasági ösztönzés elsődleges eszközének tekintik. A központi kormány arra ösztönözte a városokat, hogy ideiglenesen ne alkalmazzák a gépjárművek számára vonatkozó engedélyezési kvótákat, kiegészítve célzott, a széles körü társadalmi elfogadottságú elektromos meghajtású gépjárművek elterjedését segítő intézkedésekkel, mint a városi közlekedések átállítása elektromos buszokra. Így a potenciális vásárlók 70\%-a az elektromos járműveket preferálja, valamint az EV modellek választéka Kínában az egyik legszélesebb a világon. Az Európai 
Unióban ugyanez a folyamat - a politikai elkötelezettség ellenére - hosszabb időtartamú és kevésbé meredekebb felfutású lesz és a társadalmi elfogadottság is valamivel kisebb (40-60\%). Az Amerikai Egyesült Államokban - amennyiben továbbra is alacsonyan maradnak az olajárak és az üvegházhatású gázok kibocsátására vonatkozó szövetségi szintű elöírások nem követik az európai szigorítási trendeket - akkor ezek a tényezők egyelőre lassíthatják vagy gátolhatják az elektromobilitásba történő beruházásokat, így az EV piaci részaránya stagnálhat vagy enyhén csökkenhet. Ráadásul itt a potenciális vásárlóknak csak 10-30\% preferálná az elektromos járműveket fogyasztói döntéseinek meghozatala során (Saskia Hausler et at. 2020).

\subsection{Trendek és föbb szereplök a Li-ion akkumulátor (LIB) gyártásban}

Jelenleg az elektromos autók majdnem kizárólagosan lítium-ion akkumulátorokat használnak, mivel ezeknek nagyobb az energiasűrüségük, több töltési ciklust viselnek el. Eddig viszont kihívás volt a LIB gyártókapacitások hiánya, amely eddig nem tudta lekövetni a megnövekedett igényeket. Az elmúlt 1-1,5 évben be is mutatott számtalan elektromos autó nagyobb volumenü szériagyártása 2020-ban vagy ezt követően tud beindulni, mivel LIB gyártó kapacitást és a beszállítói láncot ki kellett építeni. (A vezető európai autógyártók nem rendelkeznek saját akkumulátorgyártással, így az elektromos hajtáslánc legköltségesebb elemét külső forrásoktól kénytelenek beszerezni).

Ezekre néhány példa: Magyarországon a Samsung SDI gödi és az SK Innovation komáromi beruházásai vagy az LG Chemicals Wroclaw-ban (Lengyelország) létesített üzeme, illetve a Tesla elektromos autói mellé kiépítette a saját LIB gyártó kapacitását. (vezetői interjúk)

A másik nagy kihívás a LIB gyártása során jelentkező környezetterhelés. Az elektromos autózás előnye, hogy a szennyezőanyagot nem helyben adja le a jármü, hanem a gyártás helyén, illetve erőmüvekben, kontrollált körülmények között. A teljes élettartam alatt kibocsátott $\mathrm{CO}_{2}$ szint függ az elektromos áram forrásától és az akkumulátor, illetve a gépjármű gyártási helyétől és a felhasznált technológiától. A Nemzetközi Energia Ügynökség (IEA) számításai szerint mindössze 25\%-kal kisebb $\mathrm{CO}_{2}$ kibocsátás történik a teljes élettartam alatt egy tisztán elektromos jármű esetében, főleg azért, mert az elektromos áram tárolására szolgáló Li-ion akkumulátorok előállítása magas $\mathrm{CO}_{2}$ kibocsátással járó folyamat és messze meghaladja a belső égésű motorokkal felszerelt járművek gyártása során keletkezett szennyezést. A Li-ion akkumulátor gyártási folyamata energiaigényes (jelentős mennyiségű elektromos áram, illetve fosszilis energiahordozó felhasználását igényli). Jelenleg egy koreai gyártású akkumulátor 
minden egyes kWh-nyi kapacitásának megtermelésével 123 kg CO 2 szabadul fel, ahogyan az az 1. ábrán látható. A jövőbeli feladat a Li-ion akkumulátor gyártási technológiájának fejlesztése a környezeti terhelés mérséklése érdekében. (Maeva Philippot et at. 2019)

1. ábra: A Li-ion akkumulátor gyártási lépései során jelentkező $\mathrm{GHG}^{2}$ kibocsátás

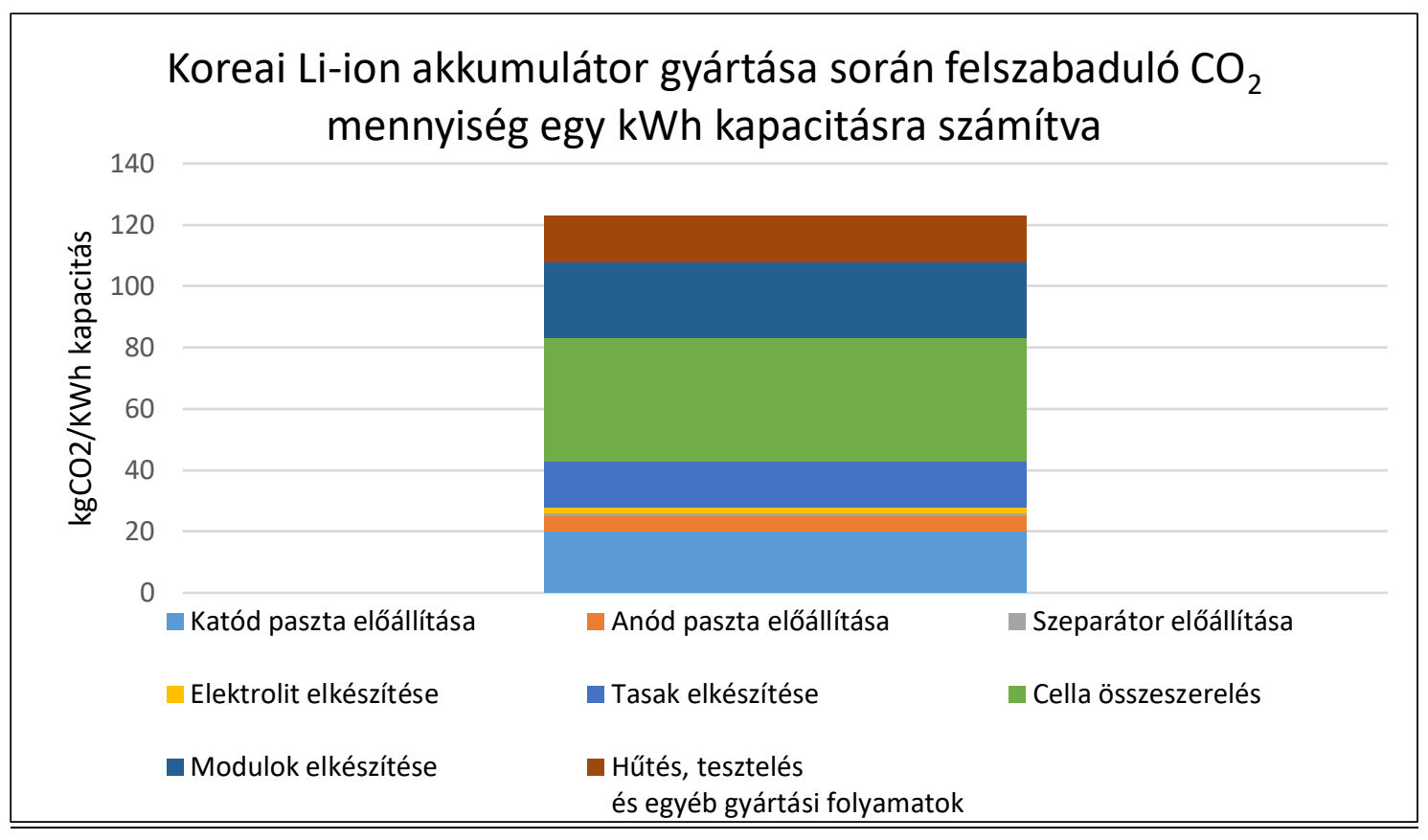

Forrás: Maeva Philippot et at. 2019 alapján saját szerkesztés

A világ lítium-ion akkumulátor igénye az elörejelzések szerint várhatóan körülbelül tízszeresére növekszik 2018 és 2030 között, elsősorban a jármüiparon belüli strukturális átrendeződés, valamint a kereskedelmi és személyszállítású elektromos jármüvek (EV) előtérbe kerülése miatt, ahogy az alábbi 2. ábrán látható.

2. ábra: Az elektromos jármüvek számára szükséges akkumulátor kapacitás

\footnotetext{
${ }^{2}$ GHG: Greenhouse Gas: üvegházhatású gázok
} 


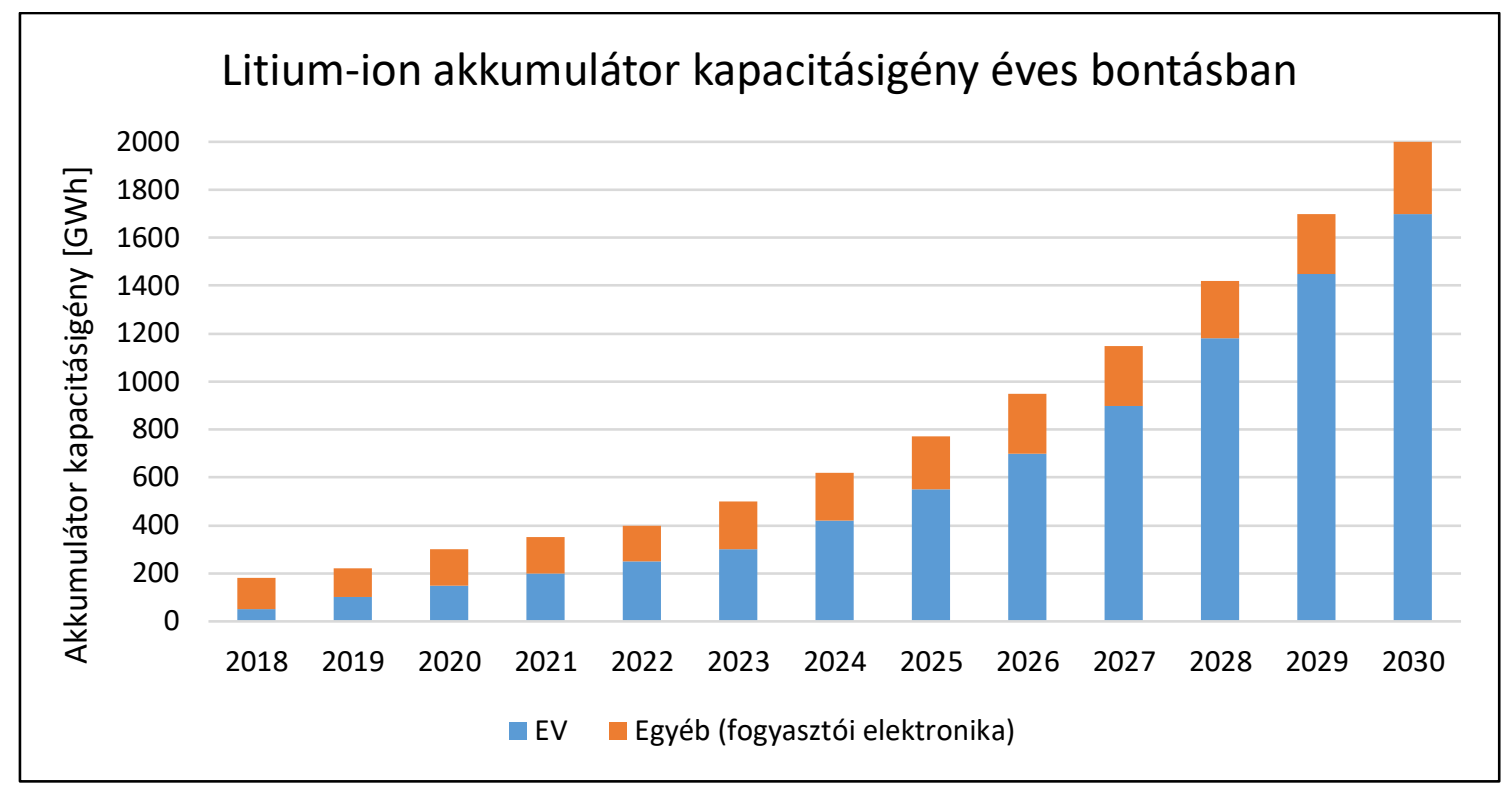

Forrás: Bloomberg NEF 2019 Electric Vehicle Outlook alapján saját szerkesztés

A lítium-ion akkumulátorok esetén a katód valamilyen fém-oxid elektróda, az itt használt anyag alapján szokás csoportosítani a különféle összetételü cellákat. A lítium-fémoxid készítése: forgó csőkemencében magas hőmérsékleten a lítiumot fémmel (kobalt és nikkel vagy mangán) oxidálják. A lítium elektródapasztát kötőanyaggal és szén hozzáadásával nagy fordulatszámú centrifugában homogén eleggyé sürítik, majd egyenletesen alumíniumfóliával vonják be. Az autóipari Li-ion akkumulátorok esetében a katód elektróda gyártásánál az alábbi komponensek kerülhetnek felhasználásra: Lítium-kobalt-oxid $\left(\mathrm{LiCoO}_{2}\right.$ - LCO); Lítium-nikkel-mangánkobalt-oxid ( $\mathrm{LiNiMnCoO}_{2}$ - NMC); Lítium-mangán-oxid ( $\mathrm{LiMn}_{2} \mathrm{O}_{4}$ - LMO); és lítiumvasfoszfát $\left(\mathrm{LiFePO}_{4}-\mathrm{LFP}\right)$. Szakértői becslések alapján a katód elektróda gyártásához felhasznált anyagok iránti globális éves igény a 2015. évi 140 ezer tonnáról 2025-re évi 400 ezer tonnára fog növekedni. Mivel a Li-ion akkumulátorok teljesítményét jelentősen befolyásolja a katód alapanyagok minősége, ezért a legnagyobb gyártók létrehozták a saját katód alapanyaggyártó kapacitásaikat. (Lebedeva, N. et at. 2016).

Az anód jellemzően természetes vagy mesterséges grafit, ez kb. $1 \mathrm{~kg}$ igen finom grafitot jelent 1kWh-ként, az elektrolit pedig folyékony lítium-hexafluorofoszfát ( $\left.\mathrm{LiPF}_{6}\right)$ vagy újabban lítium-tetrafluoroborát $\left(\mathrm{LiBF}_{4}\right)$. A lítium-polimer akkumulátoroknál a különbség, hogy a folyékony elektrolitot egy félig folyadék, félig szilárd halmazállapotú polimer gél helyettesíti. A katódot az anódtól elválasztó rész pedig a kerámia bevonatú szeparátor, amely biztosítja a Li ionok áramlását, de rövidzárlat esetén szigetelőként viselkedik. (Ogumi Zempachi et at. 2020; Arumugam Manthiram 2017) 
A világ öt legnagyobb Li-ion akkumulátorgyártó cégét a 3. ábra tünteti fel a gyártási kapacitásaik alapján.

3. A legnagyobb Li-ion akkumulátorgyártó cégek 2018-ban az éves gyártási kapacitásaik alapján

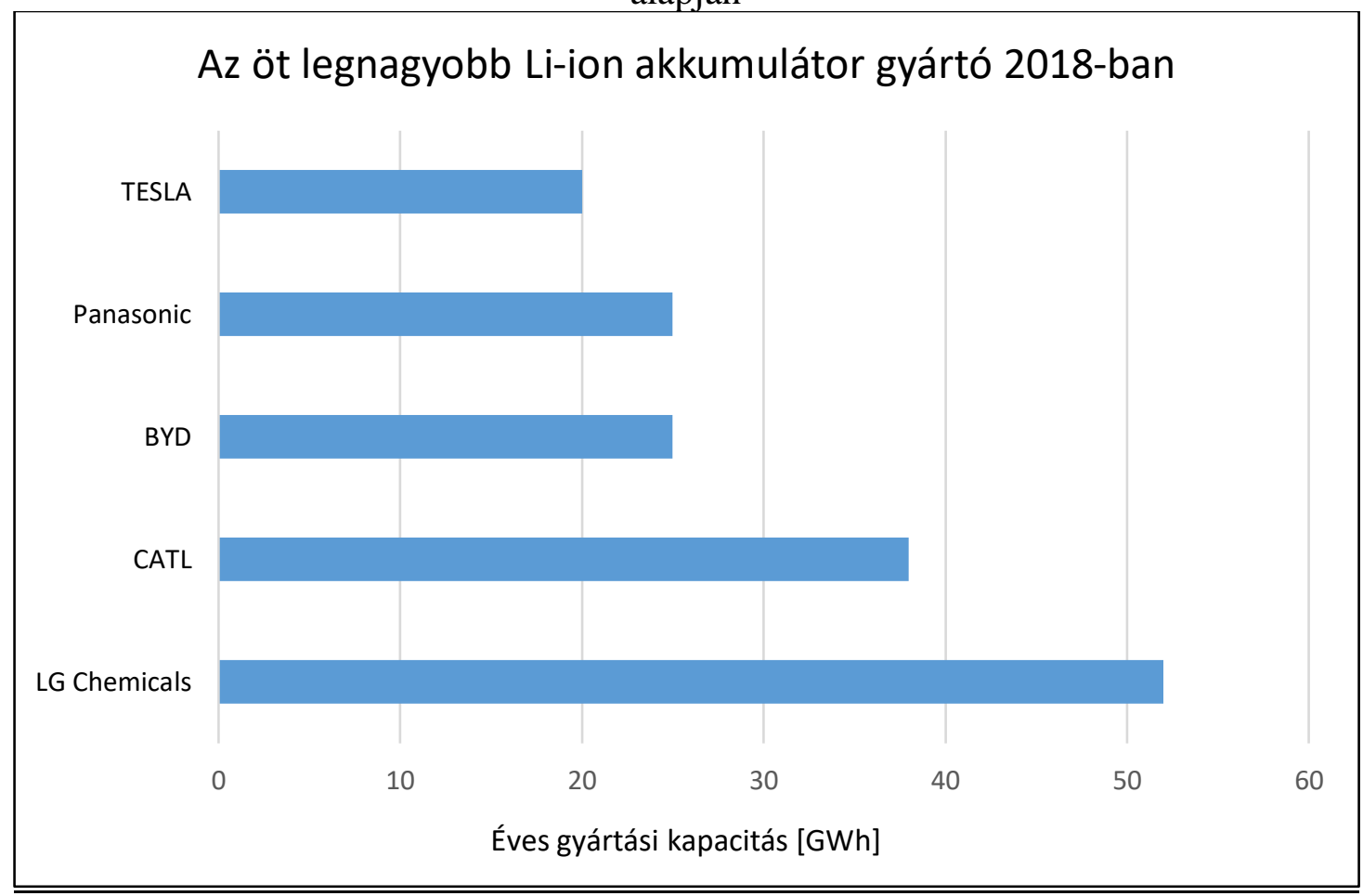

Forrás: Benchmark Intelligence alapján saját szerkesztés

Ahogyan az ábrán látható a világ legnagyobb akkumulátorgyártó cégei:

- Az LG Chemicals (Dél-Korea) a Chevrolet and Chrysler és a Nissan elektromos modelljeihez gyárt akkumulátorokat

- A CATL (Kína) számára jelenleg kihívás, hogy a másik négy versenytársa által gyártott akkumulátorokhoz hasonló minőségben állítsa elő a saját akkumulátorait.

- A BYD Company Ltd. (Kína) az akkumulátor gyártásban a világ legnagyobb kutatásfejlesztési kapacitásával rendelkezik, a fö profilja városi közlekedésre szánt elektromos autóbuszok gyártása.

- A Toyota és a Panasonic (Japán) 51:49 tulajdoni hányaddal közös vállalatot alapított 2019-ban, amelynek feladata az autóipar számára az elektromos jármúvekhez akkumulátorok gyártása.

- A TESLA (USA) a saját elektromos autóihoz kiépítette a saját akkumulátorgyártó kapacitását.

Mellettük jelentősnek számít még az SK Innovation (Dél-Korea), a Samsung SDI (DélKorea), valamint a Nortvolt (Svédország). 
Az SK Innovation mellett a szintén akkumulátorgyártásban érdekelt Samsung SDI 390 milliárd forintból bővíti gödi akkumulátorgyárát, 1200 új munkahelyet teremtve ezzel. Emellett Miskolc déli ipari parkjában építi fel első európai gyárát az akkumulátorok gyártására szakosodott japán GS Yuasa is, az üzem alapkövét 2018 márciusban helyezték el. (vezetői interjúk)

\section{Az SK Battery Hungary, Komárom}

\subsection{Elözmények}

A dél-koreai beruházóknak köszönhetően Magyarország az elektromos autók akkumulátorainak 17. legnagyobb exportőre. Az 1953-ban Sunkyoung Textile néven megalakult cég 1997-ben alakult SK Grouppá. Az SK Group a harmadik legnagyobb csebol ${ }^{3}$ Dél-Koreában. A 81 ezer alkalmazottat foglalkoztató és 2015-ben 112 milliárd USD bevételü SK Group kb.: 87 cégből áll (ebből 16 jelen van a Koreai Tőzsdéken - KOSPI és KOSDAQ), amelyek az alábbi szektorokban tevékenykednek: (Céges honlap)

- Energetika/vegyipar (ez a szektor képviseli a legnagyobb arányt - legjelentősebb cégek: SK Corporation [Dél-Korea legnagyobb olajipari vállalata, az SK Group bevételeinek kb.: 40\%-t hozza - kőolaj feldolgozás, petrolkémiai termékek, kenőanyagok]; SK Chemicals [polimer szálak és mágnesszalagok gyártása], SK Incheon Oil, az SK Gas [ez Dél-Korea cseppfolyósított földgáz nagykereskedője és disztribútora], valamint az SK Innovation)

- Távközlés/IKT (pld: SK Telekom Company Ltd., amely az SK Group árbevételének kb.: 20 százalékát hozza)

- Szolgáltatások/kereskedelem (pld: SK Networks; SK Engineering\&Construction; SK Shipping; SK Securities)

\footnotetext{
${ }^{3}$ A csebol (chaebol) a családi alapítású dél-koreai óriásvállalatok megnevezése. Ezek a vállalatok pedig nagy hatást gyakorolnak Dél-Korea gazdaságára, a Samsung cégcsoport bevételei például az ország GDP-jének 20\%-át adják. Közismert csebol cégcsoportok még például a Hyundai, a KIA, az LG, a Daewoo és az SK. A csebolok jellemzője, hogy a vállalatóriás több szektorban érdekelt, több cégből áll, és családi alapítású. A csebol családi irányítása többféleképpen is történhet. Van, ahol az alapító és családtagjai vezetik az összes céget, máshol a család irányítja az úgynevezett anyavállalatot, ami a leányvállalatokat felügyeli, így közvetett kontrollal rendelkezik az összes vállalat fölött. Lehetséges olyan struktúra is, hogy a család az anyacéget uralja, a leányvállalatok pedig egymás részvényeit birtokolják, hálózatot alkotva. A csebolok különböző gazdasági ágazatokban is tevékenykednek egyidejűleg: az elektronikai eszközök gyártásáról ismert Samsungnak egy időben autógyára is volt, de divatmárkával (FUBU) és szállodalánccal (The Shilla) is rendelkezik. Az LG Group a szórakoztató elekronikai és telekommunikációs eszközökön túl a vegyi anyagok és a műanyagok piacán is jelen van. A Hyundai áruházlánccal is rendelkezik, bár ma már ez is csak nevében tartozik a konglomerátumhoz, miután a Hyundai Groupot a 2000-es évek elején kormányzati nyomásra feldarabolták. Egy-egy csebol akár 20-50 céget is összefoghat.
} 
A Korea Oil Corporation néven megalapított cég a több mint 55 éves tevékenysége során a kőolaj kitermelés és feldolgozás mellett a vegyiparban és az elektronikai ágazatban is fontos szereplővé vált. A jelenleg SK Innovation néven működő cégnél 2006 óta gyártanak lítium-ion akkumulátorokat, partnereik között található többek között a Hyundai-KIA, a Volkswagen és a Daimler is. (interjúk alapján)

A kőolajgyártás a mai napig fontos része az SK Innovation tevékenységének. DélKoreában elsőként ők valósították meg a lítium-ion akkumulátor elválasztót, igazi versenyelőnyt szerezve ezzel az információs és elektronikaianyag-ágazatban, és az autóiparban is. Az SK Energy Korea vezető finomítója, vegyipari ágazatunk, az SK Global Chemical pedig a petrolkémiai szektor fontos szereplője. Kenőanyagüzletáguk, az SK Lubricants több mint 50 országba szállít minőségi alapolajokat, huszonöt országba pedig kész kenőanyagokat. Az SK Innovation 2005-ben kezdte meg a lítiumion-akkumulátorok fejlesztését elektromos jármüvekhez, amik 2006-ban már gyártásba is kerültek. Az első nagy mérföldkövet 2010-ben érték el, amikor Korea első elektromos autójának, a Hyundai BlueOn-jának, és a Kia Ray modelljének akkumulátor beszállítói lettek. Alig egy évvel később a Mercedes-AMG is a céget bízta meg elektromos szuperkocsija, az SLS AMG E-Cell akkumulátorának gyártásával. Így lett az SK Innovation az autógyártók megbízható partnere a világ minden részén. (interjúk alapján)

A dél-koreai daejeoni, 100 MW teljesítményü akkumulátor gyártósort 2012-ben újabb gyártósorral bővítették Seosanban, a teljesítményt 200MW-ra növelve, így ma már évente 30.000 elektromos autót tudnak ellátni akkumulátorokkal. És ez a kereslet egyre csak nő. Ezért újabb és újabb gyártósorokat és teljes gyárépületeket hoznak létre, hogy partnereik igényeit kielégíthessék. (SK BH céges weboldal)

AZ SK Innovation megrendelés-állománya akkumulátorokra a tavalyi év végére 500 GWh-ra emelkedett az egy évvel korábbi 320 GWh-ról. Kínában az SK Innovation első gyára Csangcsouban (Changzhou) 2019 második felében kezdte meg a termelést 7,5 GWh kapacitással. Az idei év végére fejeződik be a második üzem építése Jencsengben (Yancheng) 20 GWh kapacitással. Az SK Innovation befektetést tervez a kínai EVE Energy Co. Ltd. vállalatba is, ami további 8,5 GWh-val növelné meg akkumulátor-gyártási kapacitását. Kim Jun szerint 2025-re az eladott új autóknak globális szinten 10\%-át adják majd az elektromos autók, míg 2030-ra azok 20\%-át. Az SK Innovation akkumulátor-gyártási kapacitása 2030-ra eléri az évi 200 GWh-t. (céges honlap)

Az SK Innovation 2023-ban 727 millió USD beruházással az Amerikai Egyesült Államokban (Georgia államban Jackson megye) szintén felépít egy elektromos autók hajtásához alkalmas akkumulátorokat gyártó üzemet, amelynek éves termelési kapacitása 11,7 GWh áramtárolási 
kapacitású akkumulátor lesz. A későbbi tervek szerint a gyártó kapacitás bővítésére is sor kerül 1,5 milliárd USD összeggel.

Az SK Innovation, amely eddig 177,5 milliárd forintot fektetett be Magyarországon, és 750 munkahelyet teremtett, közel 100 milliárd forintos beruházással elektromos autókban használható akkumulátorcellák sorozatgyártását, valamint akkumulátormodulok és -packek összeállítását kezdte meg 2020-tól a Komáromi Ipari Parkban. (Maknics 2020; Forbes 2020)

2017-ben indultak meg a tárgyalások az SK Innovation-nal. Számukra külön E-on transzformátor házat kellett építeni a már meglevő mellé. A $120 \mathrm{kV}$ távvezeték mellett jelentős iparivíz és szennyvízkezelési igényük is volt, ezért Almásfüzitő és Komárom határában bővíteni kellett a szennyvíztelepet, illetve a Szent-Pál szigeten új kutakat kellett fúrni. (interjúk alapján)

A beruházási helyszínválasztás okai: (interjúk alapján)

- Jelentős kormányzati támogatás a beruházásokhoz a magas hozzáadott értéket előállító termelési tevékenységek és a legkorszerübb gyártási technológiák Magyarországra telepítése miatt.

- Jól képzett helyi munkaerő. (bár ezt egyre nehezebb megtalálni)

- A komáromi térség kedvező fekvése. Rendkívüli adottságokkal rendelkezik Komárom városa a közlekedés és a megközelíthetőség terén is, mivel a központban keresztezi egymást két jelentős fóútvonal az 1-es és a 13-as számú. Hatalmas forgalmat bonyolít le a hazai és nemzetközi vasútforgalom, mind személy és teherszállítás terén. Az M1es számú autópálya a településtől déli irányban 8 km-re halad el, emellett határváros is. A település jellemzői pozitívan hatnak a gazdasági szereplők bevonzására.

- Magyarország, ezen belül Komárom-Esztergom megye az európai logisztikában kedvező helyet foglal el, ezért nem zárható ki a további, újabb első és második körös (fejlesztő, kapacitásbővítő) beruházások lehetősége. Budapest-Bécs-Pozsony háromszög középpontjában fekszik a megye. Nagyon jó logisztikai adottságokkal rendelkezik a régió. - WV csoport Pozsony, Hyundai Galánta, Jaguár Nyitra, Audi Győr, Suzuki Esztergom. Megjegyzendő, hogy Komárom számára az intermodalitásban rejlő lehetőségek egyelőre még nem kellően kihasználtak. Legjelentősebb kiaknázatlan potenciált a szlovák kapcsolatok rejtik. Ennek új lökést adhat a Révkomárom-Komárom között megépülő új Duna híd és az Esztergomnál átadott teherkomp, valamint a várost az M1-es autópályával összekötő gyorsforgalmi út, továbbá a jelentős kapacitású párkányi és ebedi teherpályaudvarok tervezett 
rekonstrukciója a határon átívelö integrált területi beruházás keretében. E tervezett fejlesztések a meglévő, de alulhasznosított szlovákiai kikötő- és vasúti logisztikai kapacitásokhoz is kapcsolatot biztosíthatnak.

A vállalat Battery üzletága a Komáromi Ipari Parkban megvásárolt 43 hektáros területen létesítette első 7,5 GWh kapacitású európai gyáregységét. Az SK Battery Hungary üzemében teljesen elektromos és plug-in hibrid jármüvek akkumulátoraihoz használatos lítium-ion akkumulátorcellák, modulok és packek készülnek. A piaci környezet változása, a nagy autógyártók elektromos autózás irányába történő elmozdulása viszont újabb beruházásra ösztönözte az SK Innovation menedzsmentjét. Ennek eredményeként 2019 februárjában bejelentették: közel 239 milliárd forintból egy második akkumulátorgyárat is felépítenek majd Komáromban, amely 1000 új munkahelyet jelent. Az új egység az első gyár építéséhez megvásárolt 43 hektáros telek 11,7 hektárnyi részén fog megvalósulni, 10 GWh-val növelve az éves gyártókapacitást. A kibővített termelés 2021. évi elindításával a komáromi gyár maximális kapacitásával évi 250 ezer elektromos autóhoz biztosíthat akár 500 kilométeres hatótávot jelentő, harmadik generációs EV-akkumulátorokat.

\subsection{Az SK Battery Hungary müködése, jövöbeli tervei (interjúk alapján)}

Az SK BH szervezeti felépítése: a föbb területek élén dél-koreai menedzser van. A céges kultúra eltér a KEM-beli japán, kínai, európai és amerikai székhelyü nemzetközi nagyvállalatok helyi gyáregységeiben meglévő céges kultúrától). Ez nem a hierarchikus szervezeti struktúrában, az egyes folyamatok/technológiák müveletelemekre való lebontásában, az egyes technológiai lépések minőségbiztosított müködésében, vagy a rövid értéklánc miatti viszonylag szűk mozgástérben (KEM-ben a gyártás és az összeszerelés van, de stratégiai fejlesztési, marketing/disztribúciós döntéseket az SK Innovation koreai központjában hozzák meg) nyilvánul meg. Az eltérés lényege, hogy a dél-koreai helyi menedzsment nem szándékozik a későbbiekben sem a háttérbe vonulni és fokozatosan átadni a felső vezetői pozíciókat a helyi menedzsmentnek úgy, ahogyan például a japán tulajdonú Bridgestone Tatabánya Termelö Kft. esetében történt.

Emellett szintén a dél-koreai kultúrára jellemző, hogy az erősen hierarchikus társadalmi berendezkedés és az autokrata vezetési stílusra való hajlam és a korlátozott, sokszor egyirányú (felülről lefelé történő) információáramlás mellett, minden gyártási és müködési problémát igyekeznek „házon belül”, külföldi cégek kizárásával megoldani a horizontális és vertikális integráció keretében. Az elöre történő vertikális integrációban a cég törekszik a LIB gyártáshoz szükséges alapanyagok és egységek feletti ellenőrzés kézben tartására. Az SK Innovation erre a területre specializálódott, hasonló kultúrájú dél-koreai beszállítókkal 
dolgozik, azaz igyekszik a külföldi beszállítóktól való függőséget csökkenteni és optimalizálni a saját beszállítói láncát.

A horizontális integráció keretében a vállalat arra törekszik, hogy minél több piacon növelje az üzleti részesedését. Erre példa, hogy az SK Innovation 100\% tulajdonában lévő SK BH mellett létrejött a Volkswagen (VW) csoporttal 50-50\% tulajdonosi szerkezetủ SK Manufacturing is.

Az európai autógyártóknak egyre szigorodó károsanyag-kibocsátási követelményeknek kell megfelelniük, amelynek hatására nagyobb szerepet szánnak az elektromos autóknak a termék portfoliójukban. A termeléshez nélkülözhetetlen akkumulátorokat ázsiai beszállítóktól megvásárolják. A látványosan megugró keresletre reagálva ezek a szereplök sorra kezdték építeni európai üzemeiket, köztük volt az SK Innovation is, amelynek Komáromban már második akkumulátorgyára épül. A dél-koreai vállalat még több akkumulátort akar előállítani európai partnerének, a Volkswagennek (VW), ezért bővíteni fogja a második komáromi üzemét, amely így a korábbi 10 GWh helyett összesen 16 GWh-val növeli az éves gyártókapacitást. A VW csoporttal közös vegyesvállalat (50-50\% tulajdoni részarány) SK Manufacturing néven fog múködni. (interjúk alapján)

Az elektromos hajtásláncok erőforrásainak (LIB) a gyártási technológiája - bár magas hozzáadott értéket jelentő termékről van szó - kevésbé összetett, mint a hagyományos belső égésű robbanómotorral (ICE) felszerelt gépjárművek erőforrásainak a gyártása, valamint azokhoz viszonyítva költséghatékonyabb tevékenység. A cellák gyártási költségeit az anyag és energiafelhasználás (10\%); a munkaerő bér és járulék költségei (10\%), a minőségbiztosítási, karbantartási folyamatok (20\%), valamint az értékcsökkenés (60\%) adódnak.

A SK BH által alkalmazott LIB gyártási technológiákat sehol máshol nem lehet megtanulni, azok speciális, egyedi jellege miatt. Ugyanezen okból az ICE autókat gyártó cégeknél és ezek beszállítóinál elsajátított szakmai ismeretek (néhány kivételtől eltekintve) nem adaptálhatók. A gyártási folyamatok hatékonyságának és minőségi színvonalának emelése érdekében minden innovatív megoldásra nyitottak.

Termelés: 5 gyártósor (ebböl jelenleg 3 üzemel, a másik kettő 2020. végére lesz üzembe helyezve). A gyártási kapacitások teljes felfuttatásával évente 250 ezer elektromos autóhoz tudnak Li-ion akkumulátort biztosítani.

A gyártási folyamat részei:

- elektróda gyártás

- cella összeszerelés

- formázás 
Gyártás támogatás: Logisztika, $\mathrm{EHS}^{4}$ (tűz, katasztrófavédelem, ipari biztonság), Utility

Minőségügy: gyártás előtti alapanyagok ellenőrzése, gyártás közbeni és végellenőrzés

Általános támogató terület: pénzügy, HR, beszerzés

Az SK BH jelenleg 1200 fő munkavállalót foglalkoztat, amelynek 19-20\%-a szlovák állampolgár (Felvidék); 1\%-a pedig dél-koreai. A teljes munkavállalói létszámból 800 fó operator, 30 fö pedig mérnök. A felsőfokú müszaki végzettségüek terén a cégnek folyamatmérnökökre és minőségügyi mérnökökre van szüksége vegyészmérnöki, villamos mérnöki, mechatronikai mérnöki háttérrel. A müszaki menedzsereket nem preferálják.

Az SK Innovation által létesített két magyarországi SKBH gyárának együttes értéke 416 milliárd forint, és összesen 2500 embert fog foglalkoztatni a beruházásokat követően a gyártókapacitások teljes felfuttatásával.

\section{Következtetések}

Az SK Battery Hungary Kft. üzleti folyamataira a koronavírus járvány nem gyakorolt szignifikáns hatást.

Ennek valószínüsíthető okai (az interjúk alapján):

- Az elektromos autók piaci szegmensét a járvány nem vetette vissza annyira, mint a jármúipart összességében. Míg a hagyományos belsőégésű motoros autók (ICE) iránti kereslet visszaesett a járvány kitörését követő időszakban, addig a 27 EU-tagállam összességében a külsőleg tölthető elektromos személygépkocsik (a tisztán elektromos BEV és a plug-in hibrid PHEV kategóriák) piaci részesedése az egy évvel korábbinak a duplájára emelkedett, több mint 167 ezer autó eladásával 6,8\%-ra. Vagyis Európában minden tizenötödik eladott személygépkocsi elektromos volt március végéig. Magyarországon az első negyedév negatív tendenciái érvényesültek mind az új, mind a használtan külföldről behozott autók értékesítésében. Az elöbbiek esetében a visszaesés 4,9\%-os, az utóbbiaknál 4\%-os volt március végéig, majd lényegében befagyott a piac.

\footnotetext{
${ }^{4}$ A magyarországi gyártó cégeknél keresettek az EHS koordinátorok. Azért van szükség rájuk - általában helyben, saját alkalmazottként - mivel különböző veszélyességi fokú gyártó gépekkel, hatalmas csarnokokban dolgozik pár száztól több ezer föig nagyon sok munkavállaló. Az EHS koordinátorok legfőbb feladata egy gyártó cégnél, hogy a megfelelő munkavédelmi, környezetvédelmi vagy tüzvédelmi intézkedéseket létrehozzák, kialakítsák és betartassák a szervezeten belül. Munkavédelemhez hozzátartozik a megfelelő védőruha alkalmazásától kezdve a biztonságos utakon való haladás a gyártócsarnokon belül. Amennyiben egészségre káros üzemi környezetröl beszélünk, csökkenteni kell a kockázatát az üzemi baleseteknek és fokozni kell a munkavállalók hosszú távú egészségének megóvását (pl esetleges halláskárosodás a zajos gépek mellett). Ha a gyártó cég gyártás közben bármilyen környezetre káros mellékterméket termel, ennek a megfelelő kezelése, eltávolítása (pl. szennyvíz elvezetése) felkerül a megoldandó feladatok listájára az EHS-es kollégához. (interjúk alapján)
} 
Az elektromos szegmensben azonban látványos volt a növekedés: a BEV és PHEV jármüvek piaci részesedése elérte a 3\%-ot.

- Az Európai Unió vezetői erőteljesen elkötelezték magukat a járvány utáni „zöld gazdasági újjáépítés" mellett, és ebben Magyarország is kivételes iparfejlesztési lehetőséget lát. A tagállamoknak a gazdasági szektorok - mint az energia és a közlekedés összekapcsolásával kell új értékláncokat teremteni. Ennek mentén alakulnak ki olyan okos mikrohálózatok, amelyek nagymértékben digitalizáltak, és képesek kezelni az elektromos járművek töltése mellett a különböző energiatárolási technológiákat is.

- A komáromi gyár 2020. januárjában indította el a sorozatgyártást, egy elöre meghatározott gyártási ütemterv és megrendelés állomány alapján. Az éppen felfutóban lévő gyártókapacitás még nem érte el a maximumát 2020. március 11-ig, amikor Magyarországon kihirdetésre került a járványügyi vészhelyzet. A járvány ellenére a termelés bővülése és az új munkatársak felvétele változatlan ütemben folyt és jelenleg is folyik. (Egy már teljes kapacitáson müködő üzemnél talán más lehetett volna a COVID-19 hatása). A cég egyébként készül a 2020. végén esedékes, a járműipari beszállítók számára kötelező IATF 16949 auditra.

- Az SK Innovation első és második körös beszállítói (TIER 1. és TIER 2.) túlnyomórészt szintén dél-koreai cégek közül kerülnek ki, azaz a vállalat igyekszik a külföldi beszállítóktól való függőséget és a globalizált, sokszereplős, hosszú és sérülékeny beszállítói láncok hatásait kiküszöbölni.

- A járvány felszínre hozta a kontinenseken átnyúló, koncentrált termelési láncok problémáit. Az erős piaci verseny által kikényszerített költséghatékonyság, a minőségre és a méretgazdaságosságra való törekvés mellett látszik, hogy számos terméknek (alapanyag, alkatrészek, részegységek) van kevés számú, vagy egyetlen termelöje, sokszor egy távoli országban. A just-in-time rendszerek egyre szélesebb körben való bevezetése, a szigorú készletgazdálkodás pedig még elősegítette a struktúra sérülékenységét. A kialakuló hiány pedig hirtelen kezelendő komoly problémává vált.

- A méretgazdaságosság kérdése továbbra sem lesz megkerülhető, nem gyárthat minden ország mindent. Ugyanakkor valószínü - és erre állami ösztönzők is jönnek majd - hogy a nagy gazdasági régiók - az USA, Európa és Kína a hozzájuk kapcsolódó "szatellit" területekkel a mostaninál önállóbb termelési centrumokká alakulnak majd bizonyos termékek esetében, a nagy régiók közötti kereskedelem pedig a korábbinál kevésbé lesz intenzív.

- A jövőben nem akar majd egyetlen ország sem arra kényszerülni, hogy másoktól kérjen segítséget a kialakuló hiányok kezelésének érdekében, illetve vállalati 
szinten is fontos lesz ezen kockázatok kezelése. Ebbe a sorba beilleszkedik az SK BH vállalati stratégiája is.

- Az SKBH LIB gyártósorainak ellátására a LIB négy fó komponensét biztosító cégek zöme azonos kultúra és értékrend mentén müködő dél-koreai csebol, amelyek szintén KEM telephelyet választottak maguknak, követve Magyarországra az SK Innovation-t: Doosan (Környe), Lotte Aluminium (Tatabánya), Soulbrain (Tatabánya) lerövidítve a globális beszállítói láncokat.

A koronavírus által előidézett gazdasági recesszió miatt (reálgazdasági és pénzpiaci bizonytalanságok),,visszalassultak a dolgok”, de a rugalmasság, kreativitás is segíthet a talpon maradásban. A cég nyitott a korszerü vezetési és menedzsment módszerek elsajátítását célzó tudástranszferre is, müködésének még hatékonyabbá tétele érdekében.

\section{6. Összefoglalás}

A COVID-19 járvány negatív hatásai érezhetők voltak globális szinten a hagyományos belsőégésü motoros személygépkocsikat és haszongépjármüveket gyártó és értékesítő jármüipari szektorban is, mivel a legtöbb jármügyártó (OEM) leállásra vagy csökkentett üzemmódban történő müködésre kényszerült egyrészt a globális beszállítói láncok leállása miatt, ahonnan a gyártáshoz szükséges alapanyagok és alkatrészek beszerzése történt. A járvány terjedésének lassítását célzó karantén-intézkedések miatti gazdasági recesszió következtében pedig az ügyfelek elhalasztották az új ICE gépjárművásárlási döntéseiket, a megrendelés állomány drasztikus zsugorodását előidézve.

Ugyanakkor a jármüipar EV szegmensében a járvány hatásai jóval mérsékeltebbek voltak. Az elektromos hajtásláncú járművek iránti kereslet nem, vagy csak minimális mértékben esett vissza, és a piaci részarányuk szignifikánsan növekedni fog a globális jármüpiacon belül a közeljövőben. Köszönhető ez az egyre szigorodó klíma- és környezetvédelmi előírásoknak, a gazdaság zöldítésére vonatkozó törekvéseknek társulva az EV elterjedését célzó állami szubvenciókkal is.

Az elmúlt évek trendjei alapján Magyarország - ahol szintén jelentős gazdasági súlyt képvisel a feldolgozóiparon belül a jármüipar - kihasználhatja a jármüiparon belüli szerkezeti átrendezésből adódó lehetőségeket. 2018-2020 között több jelentős dél-koreai, japán és kínai, az EV gyártásban, illetve ezek erőforrásainak (LIB) előállításában érintett cég választotta Magyarországot (és ezen belül néhány Komárom-Esztergom megyét) gyártási kapacitásbővítésének európai színhelyéül. 
Az esettanulmányban bemutatott, LIB gyártó komáromi SK BH üzleti folyamataira a járvány nem gyakorolt hatást, a felfutóban lévő gyártó kapacitások kiépítése zavartalanul folytatódott. Ennek okai az EV iránti kereslet jövőbeli felfutása mellett a dél-koreai céges kultúrában keresendő, amely mindig is törekedett a külföldtől való függetlenedésre. Ez megnyilvánul a saját beszállítói láncának rövidítésében és optimalizálásában (a szintén Komárom-Esztergom megyébe betelepült dél-koreai beszállítókkal és alvállalkozókkal dolgoztatás), amely sikeresnek bizonyulhat a későbbiekben is, csökkentve a járvány hatásainak való kitettséget.

A koronavírustól függetlenül az utóbbi időben elindult egy alkalmazkodási folyamat a magyar cégek körében is, amelyek szintén igyekeznek újra pozícionálni a termelésüket, újra gondolva a munkaerő kapacitást, a termelési láncstruktúrát és a készletezési politikát. Ebben segíthet a fenti példa végig gondolása is.

Másfelől a megyei KKV-k egyelöre nem rendelkeznek azzal a kapacitással, technológiai tudással, tőkével, menedzsment, szervezeti és munkakultúrával, amely lehetővé tenné, hogy az SK BH 1. vagy 2. vonalas beszállítói körébe bekerülhessenek importot kiváltó helyettesítő termékekkel, magas hozzáadott értékü szolgáltatásokkal (energiamenedzsment, hulladékgazdálkodás, prediktív analitikai szolgáltatások). Azonban az LIB gyártókapacitások Komárom-Esztergom megyébe történő telepítése számos jól fizetett munkahelyet teremt, amely fizetőképes keresletet generál. A helyi cégeknek ezen igények kielégítésére lenne célszerü törekedniük helyben előállított, jó minőségű és környezetbarát termékkel és szolgáltatásokkal, amire fel lehet őket készíteni és ebben az Edutus Egyetemnek is lesznek feladatai. 


\section{Felhasznált irodalom}

1. OECD (2020): Coronavirus (COVID-19): SME Policy Responses; Hungary 76-77 p.

2. Bloomberg NEF 2019 Electric Vehicle Outlook

3. Lebedeva, N., Di Persio, F., Boon-Brett, L.: Lithium ion battery value chain and related opportunities for Europe, European Commission, Petten, 2016

4. Ogumi, Zempachi \& Arai, Hajime \& Abe, Takeshi \& Morita, Masayuki. (2020). Present LIB Chemistries. 1-35. doi 10.1002/9783527610426.bard110005.

5. Budde-Meiwes, Heide \& Drillkens, Julia \& Lunz, Benedikt \& Muennix, Jens \& Lehner (maiden name Rothgang), Susanne \& Kowal, Julia \& Sauer, Dirk (2013): A review of current automotive battery technology and future prospects. Proceedings of the Institution of Mechanical Engineers, Part D: Journal of Automobile Engineering. 227(5); 761-776.; doi 10.1177/0954407013485567.

6. Maeva Philippot; Garbiñe Alvarez;, Elixabete Ayerbe; Joeri Van Mierlo; and Maarten Messagie: Eco-Efficiency of a Lithium-Ion Battery for Electric Vehicles: Influence of Manufacturing Country and Commodity Prices on GHG Emissions and Co Batteries 2019, 5, 23 doi:10.3390/batteries5010023

7. Arumugam Manthiram (2017): An Outlook on Lithium Ion Battery Technology ACS Central Science doi: 10.1021/acscentsci.7b00288

8. Jae C. Jung; Elizabet Sharon (2019): The Volkswagen emissions scandal and its aftermath Global Business and Organisational Excellence 38 (4) 6-15; doi: 10.1002/joe.21930

9. Christian Brand (2016): Beyond 'Dieselgate': Implications of unaccounted and future air pollutant emissions and energy use for cars in the United Kingdom Energy Policy Vol. 97, 1-12; doi:

10. Janene Pieters (2017): Netherlands suspects Fiat of Diesel software fraud https://nltimes.n1/2017/07/11/netherlands-suspects-fiat-diesel-software-fraud 2020.07.03.

11. Janene Pieters (2020): Suzuki and Jeep cought messing with emission tests https://nltimes.nl/2020/01/23/suzuki-jeep-caught-messing-emission-tests 2020.07.03.

12. IEA (2020), Global EV Outlook 2020, IEA, Paris https://www.iea.org/reports/global-evoutlook-2020 2020.07.03.

13. Európai Bizottság (2019): A Bizottság közleménye. Az európai zöld megállapodás COM (2019) 640. final

14. European Environment Agency /EEA/ (2018): Electric vehicles from life cycle and circular economy perspectives; TERM 2018: Transport and Environment Reporting Mechanism (TERM) report No 13/2018 ISSN 1977-8449; doi:10.2800/77428

15. Benchmark Mineral Intelligence: Who is winning the global lithium ion battery arms race? https://www.benchmarkminerals.com/who-is-winning-the-global-lithium-ion-batteryarms-race/ 2020.07.06.

16. Yeon Baik, Russell Hensley, Patrick Hertzke, and Stefan Knupfer (2019): Making electric vehicles profitable MacKinsey \& Company https://www.mckinsey.com/industries/automotive-and-assembly/our-insights/makingelectric-vehicles-profitable\# 2020.07.02. 
17. Saskia Hausler, Kersten Heineke, Russell Hensley, Timo Möller, Dennis Schwedhelm, and Pei Shen (2020): The impact of COVID-19 on future mobility solutions; MacKinsey \& Company https://www.mckinsey.com/industries/automotive-and-assembly/ourinsights/the-impact-of-covid-19-on-future-mobility-solutions 2020.07.09.

18. Forbes: Miközben a világ Kínára figyel, ázsiai cégek egy magyar megyében építik az elektromos autók mini-Detroitját 2020 https://forbes.hu/uzlet/mikozben-a-vilag-kinarafigyel-azsiai-cegek-egy-magyar-megyeben-epitik-az-elektromos-autok-mini-detroitjat/ 2020.07.03.

19. Maknics Zoltán (2020): Komárom-Esztergom Megye Gazdasága, TOP-100 https://www.kemkik.hu/hu/komarom-esztergom-megyei-kereskedelmi-esiparkamara/cikkek/top-100-komarom-esztergom-megye-gazdasaga-111115 2020.07.03.

20. SK Battery Hungary céges weboldal: https://www.skbhungary.com/en/ 2020.07.03. 